\title{
CSR, environment-friendly investments and innovations - the three elements necessary to build a modern and strong coal mining company?
}

\author{
Katarzyna Hałasik ${ }^{2}$ and Joanna Kulczycka ${ }^{1, a}$ \\ ${ }^{1}$ Mineral and Energy Economy Research Institute, Polish Academy of Sciences, Krakow, Poland \\ ${ }^{2}$ AGH-UST, AGH University of Science and Technology, Faculty of Management, Krakow, Poland
}

\begin{abstract}
Currently, strongly increasing globalization forces companies around the world to search new ways to build competitive advantage and achieving goals. Society having wider access to information and products, began to pay attention not only to the attractiveness of the goods, but also to the credibility of the environmental and social of functioning companies. This makes, that the concept of corporate social responsibility and the green revolution, which are strongly associated with innovations, in last years become widely discussed in the literature, as well as popular in the activities of enterprises. This article is an attempt to answer the question, whether the combination of these three elements is a guarantee for the creations of a positive image, and thus the value of a modern and strong company. The research literature aims to identify the current approach to these three factors and their characteristics. In contrast, the analysis of Polish hard coal mining sector indicates the role of innovation, environmental protection and CSR in the industry - whether the actions in this area are present and to what extent. In addition, it will be presented to outline the current state of Polish hard coal mining sector.
\end{abstract}

\section{Introduction}

Exponential technological progress that took place during recent years has caused a series of far-reaching changes in the world. The first immediate result was undoubtedly created a number of innovative products and services. Further consequences are now the changes on many levels: the social, organizational or cultural, related to the process of globalization and faster flow of information, capital and goods.

As a result of these changes, we began to pay much attention to the ethical, environmental or social matters within the organization. Consequently, companies that pay little attention to zero emissions, pollution prevention, ecolabelling and other environmentally related matters will sooner or later loose their customers [1]. The growing popularity of corporate social responsibility (CSR) and sustainable development also confirms changes, that have occurred in the perception of the main objectives and values which should guide the functioning of companies. In recent years in Poland the entrepreneurs' interest in the concept of sustainable development and CSR has been increased - the analysis of reports from studies enables to note positive changes in a way of thinking and perception of CSR by the Polish entrepreneurs and managers, though it is still far to satisfactory results $[2]$.

\footnotetext{
${ }^{\mathrm{a}}$ Corresponding author: kulczycka@meeri.pl
}

This article aims to illustrate the current situation of Polish hard coal mining sector, in the context of the implementation of the assumptions arising from the concept of CSR, environmental protection and innovation. The aim is to assess achieved benefits and costs for these reasons. This will enable to present an answer to the question, whether these factors are the basis for building a competitive advantage and a source of a number of other benefits for companies in the sector which interferes with the natural environment.

\section{Main principles coming of CSR for modern enterprises}

The growing popularity of CSR makes companies begin to function under social pressure. It is expected, that their actions do not only meet the requirements of ethical and environmental within the law, but at the same time meet the expectations of different social groups. As indicated by Jenkins (2009) [3], CSR relates to the activities of businesses, particularly in terms of their contribution to achieving economic, social and environmental sustainability. To remain competitive, companies need to be able to adapt to these new demands from the market and society in which they operate.

CSR, despite its popularity, is still variously defined and understood. In addition, in the literature you can meet different positions regarding the significance of CSR, which is making even more controversies surrounding 
the theory. In the 1990 s, but also presently there are views that the whole concept is not relevant for business (Freeman \& Liedtke, 1991) [4], by those who see the importance, but say it is a bad business idea (Friedman, 1962) [5] for a wide range of different authors, who believe that CSR is of strategic importance for the business [6]. Therefore, while investigating the CSR we have to take into account the fact that different countries have different priorities and values that shape the way business operates [7], which also has a decisive influence the knowledge and practice issues of responsible business.

CSR derives from business ethics, and the growth of interest showed mostly large companies in order to overcome the anti-globalization and anti-capitalist protests in the $90 \mathrm{~s}$ of the 20th century [8]. Informing about the actions taken and their results is still voluntary, however on 12.06.2014 for large companies (meeting the criteria for the employment over 500 people and balance sheet total over EUR 20 million, or income over EUR 40 million) came into force the EU directive on disclosure of publication non-financial information and information on the diversity of some large companies and groups. Poland and other EU countries are obliged to implement the provisions of the directive into national law by 12.06 .2016 . However, recognition of CSR is current also among small and medium-sized enterprises (SMEs), which began to practice CSR activities.

Among the many definitions, as an example you can quote those created by international institutions, such as: - the definition given by the European Commission, according to which corporate social responsibility is a concept whereby companies integrate social and environmental concerns in their business operations and in their interaction with their stakeholders on a voluntary basis [9],

- the definition in accordance with ISO 26000, which says that social responsibility means inclusion by business of social and environmental concerns in the commercial (economic) activities and taking responsibility for the impact of their activities on society and the environment [10],

or in the national context, such as the definition given by the Ministry of Economy in Poland, according to which:

- the basic premise of CSR is responsible and ethical conduct of business in relation to social groups, which interacts with the greatest possible respect for the natural environment. Building a socially responsible business model based on the concept of sustainable development, stressing the need to take into account in business, in addition to the economic dimension, the social and environmental factors in order to meet the needs of not only the present but also for future generations [11]. Indicated definitions clearly show obligations of enterprises, arising from the implementation of CSR principles. However, the important issue need to be borne in mind is that, a properly implemented CSR strategy also leads to raise a number of benefits and intangible. Most frequently reported are:

- increased interest of investors,

- extending the consumers and stakeholders loyalty,
- improvement of relations with the community and local government,

- increased competitiveness,

- improvement of the organizational culture of the company,

- shaping a positive image of the company among employees,

- obtainment and retention the best employees [12].

Benefits obtained from CSR depend primarily on the scope and implementation of CSR activities, their level of implementation and fitting to the strategy of the entire enterprise, the correct understanding of the theory and tools which were used. In this range, a number of international institution formulate standards for reporting, for example GRI. Guidelines of the Global Reporting Initiative (GRI), include a benchmark reporting corporate responsibility and sustainable development for companies around the world [13]. As indicated by Levy, Sznejwald Brown and de Jong (2010) [14] standards GRI has become embedded in the operational routines and practices of hundreds of large companies in multiple countries. It has gained widespread legitimacy, as demonstrated not just by corporate compliance, but also by the attainment of official recognition by governmental agencies and multilateral organizations such as the UN Global Compact [14]. The principal aim of GRI is that corporate social responsibility has become a reliable and routine reporting tool, such as financial reporting [15]. The principles promoted by GRI are a number of clear guidelines and rules regarding the reporting of companies on the basis of sustainable development and CSR, formulated in such a way that they can be used in the most of enterprise. The first guidelines G1 were issued in 2000, while in 2011 five supplements were published: for companies from the energy industry, financial services, food processing, mining and metals, and non-governmental organizations, which include sets of additional indicators reporting for companies [15]. The latest and current guidelines are G4.

\section{Implementation of CSR as a straight path to innovation and environmental protection}

CSR is not the only, popular in recent years, way to find new sources of competitive advantage and other intangible benefits for businesses around the world. With the development of technology, many companies began to invest in innovative projects, often promoting environmental protection. Innovations are strongly stimulated not only by new technologies, the development of technical skills and consumer demands, but also by strong and global the importance of CSR issues. Companies in order to be successful and innovative nowadays, must consider the social and environmental impact of their operational processes, stimulate the creativity of their workforce, and cooperate with their suppliers, customers, and other business partners in designing and developing new and innovative products and services [7]. Admittedly, as indicated 
by Bocquet and Mothe (2013) [16], on an academic ground, the relationship between CSR and technological innovation has still not been evidenced. In literature definitions of CSR does not relate directly to the issue of innovation. On the other hand, the strategic management and dynamic evolutionary approaches offer an interesting angle for reconciling CSR and technological innovation [16].

To investigate, whether CSR can become a source of innovation, and hence a number of intangible benefits for the company, the relationship between CSR and innovation should be considered. CSR has opened the way for many innovative products and processes, in particular ecology and prosocial. Gallego-Alvarez, Manuel Prado-Lorenzo Garcia-Sanchez (2011), studying the relationship between innovation and CSR proposed to formulate the following hypotheses:

- there is a bidirectional relationship between CSR practices and investment in innovation,

- CSR practices positively influence the volume of investment in innovation,

- investments in innovation positively influence CSR practices [17].

Thus, there is a positive correlation between investments in innovation and CSR. This is confirmed by research done by MacGregor and Fontrodona (2008) [18] on SMEs had either a proactive or a reactive approach to CSR and innovation. It has been shown that: - the most successful companies were proactive in their approach and also, interestingly, had the highest level of CSR implementation,

- proactive CSR is easier than proactive innovation,

- CSR adoption can be a starting point for proactive innovation and also for companies that want to improve their position in their industry but are generally riskaverse [7].

Important combination of CSR and innovation are the eco-innovation. The Organisation for Economic Co-operation and Development (OECD) clearly defined, what is meant by eco-innovation: Innovation that reflects the concept's explicit emphasis on a reduction of environmental impact, whether such an effect is intended or not. It is not limited to innovation in products, processes, marketing methods and organisational methods, but also includes innovation in social and institutional structures [19]. As indicated by Rexhepi, Kurtishi and Bexheti (2013) [7], eco-innovation is thus seen as an overarching concept which:

- provides direction and vision for pursuing the overall societal changes needed to achieve sustainable development,

- leads to progress in eco-efficiency, and eco-efficiency is a management philosophy to guide and measure companies and other actors' development in environmental performance.

Such an approach to eco-activity, shows that it is very strongly associated with CSR - is a kind of tool to realize CSR' assumptions related to the environment it is intended to create value by reducing the negative impact on the environment. There's a definition of CSR which says: CSR is a concept, in which the organization functioning in the environment, voluntarily takes into account its expectations and the responsibility to care for it [20]. Surroundings, in this context, means all stakeholder groups, in other words entities that are under the influence of the organization or have an influence on it. Keep in mind that according to the concept of CSR, the natural environment is also a stakeholder. Therefore, there cannot be activity in the field of responsible business without an activity to protect the environment.

Despite the strong correlation between CSR, ecoinnovation and environmental protection, as well as the growing awareness of ecological and social in Poland, the specificity of the Polish market imposes many barriers to these issues. According to Zuzek (2015), the most common include:

- economic factors (eco-investitions tie in with considerable financial expenditures: equipment, procedures, transaction costs)

- a complex organization (eco-innovation involves various disciplines and a large number of actors from different areas of research)

- the need for well understanding and vision of future needs (relative lack of clarity environmental issues and information problems occurring in the process of eco-innovation) [21].

Poland among EU countries is seen as a country with one of the lowest levels of implementation of eco-innovation, and this situation has not been changed for several years (Figure 1). The Eco-Innovation index based on indicators in five areas: eco-innovation inputs, eco-innovation activities, eco-innovation outputs, resource efficiency outcomes and socio-economic outcomes [22]. This confirms that in Poland there are many barriers (mostly economic barriers) to the implementation of eco-innovative solutions. Responsible field of business without an activity to protect the environment.

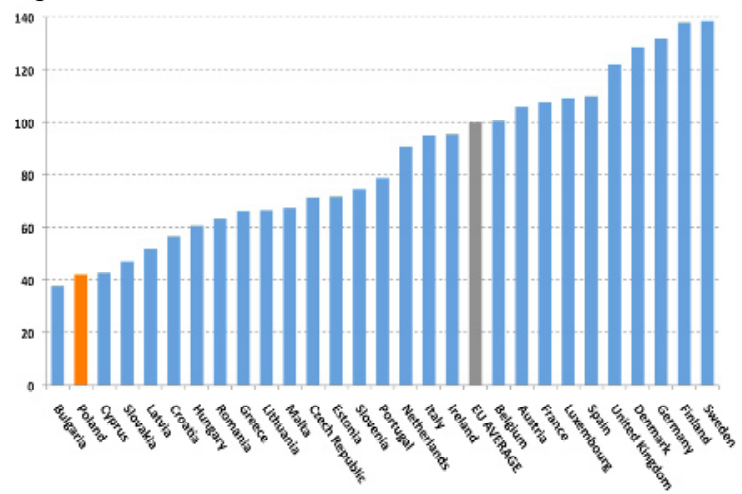

Figure 1. The level of implementation of eco-innovation in the EU - April 2014 [23]

Increasingly common practice of CSR, as well as the availability of funds for pro-environmental investment give hope, that in the near future this unfavorable trend will change and there will be new eco-innovative solutions, which are increasingly visible in the mining industry. This could be proven by the activity of KGHM Polska Miedź, which spends on environmental investments in Poland about 180 million PLN [24] every year or by an example 
of eco-innovation developed in the Central Mining Institute in Katowice (GIG), in collaboration with the Mine Limestone "Morawica" SA, in the form of a mixture of limestone, on the basis of limestone from "Morawica" Mine and waste materials from energy which is applicable in various mining techniques [25].

\section{The methodology and the current situation of the Polish hard coal mining sector}

\subsection{Methodology of research}

As shown Kulczycka and Wirth (2010) [26], a lot of mining companies in Poland take a number of CSR activities, environmental protection, promotion of local employment, investment in new projects, increase spending on R\&D. But usually, there is a lack of publicly available information in this area, and mining companies which begin investments are often treated by the local community as a threat. It is recommended to create coordinated CSR activities, in the whole mining industry and implement standards for reporting in this industry, containing the joint declarations and missions [26].

This applies particularly to the hard coal mining industry, which on grounds of a significant impact on the environment, but also of great importance for regional development should clearly inform about the strategic actions affecting local communities. Therefore, the aim is to analyze, on the basis of publicly available information and reports, the activities of companies Polish hard coal mining sector companies in terms of CSR, innovation, eco-innovation and environmental protection. These activities will be confronted with the financial results of the investigated companies.

\subsection{Polish hard coal sector}

Currently, Polish hard coal sector includes eight companies, which deal with hard coal mining:

1. Kompania Węglowa S.A. (100\% owned by the State Treasury) - 15 mines,

2. Katowicka Grupa Kapitałowa $(100 \%$ owned by the State Treasury) - it consists of Katowicki Holding Węglowy S.A., includes 4 mines and KWK Kazimierz Juliusz, includes 1 mine, which $100 \%$ of shares has KHW S.A.,

3. Jastrzębska Spółka Węglowa S.A. (listed on the Warsaw Stock Exchange, the majority shareholder is the State Treasury) - 5 mines

4. Południowy Koncern Węglowy S.A. - 1 mine, which $50.45 \%$ shares has a Kompania Węglowa S.A. and $49.55 \%$ Południowy Koncern Energetyczny S.A.

5. Lubelski Węgiel „Bogdanka” S.A. (listed on the Warsaw Stock Exchange, in which the State Treasury holds no shares)

6. Przedsiębiorstwo Górnicze Silesia (private company, which is joined ownership by Czech group Energetický a Průmyslový Holding and employees of PG Silesia)
7. Siltech Sp. z o.o. (100\% owned by a private owner) 8. Spółka Restrukturyzacji Kopalń S.A. (leads the liquidation of mines and utilizes non-productive assets of closed mines) [27].

It should be emphasized that the both mining of hard coal and lignite in Poland are very essential. These are the basic raw materials for the production of electricity in the country ( $88 \%$ of the energy came from coal in 2012 [28]). Unfortunately, most of the technology which is used is outdated and unprofitable, that is why the issue of investment and eco-innovations are so important for the energy security of the country.

Another factor demonstrating the validity of the hard coal mining industry in Poland are social and environmental factors. The deployment of mines is regionally focused on the areas with mining culture and traditions. The social, environmental and economic consequences of closing Polish mines would be significant - mass layoffs, reclamation of mining areas (removal of equipment, cleaning the area, etc.) would absorb enormous financial expenditure [29]. Therefore, new investments, social acceptance and meeting the environmental standards for the sector of hard coal mining in Poland are extremely important, in the context of the functioning of the whole country.

\section{The analysis of selected entities in the mining sector in Poland in terms of innovation, CSR and environmental protection}

The analysis was carried out in two stages for the analyzed companies: first for CSR activities and second for investments in innovation and contribution to the protection of the environment, which will allow for comparison of companies surveyed in a given range. Then it will be compared the indicator of the return on sales for 2014, to compare the activity of the analyzed range to companies' financial position. The criterion for selection of companies for the analysis was the access to the information needed for analysis.

In Table 1 are summarized the CSR activities for the Kompania Węglowa S.A., Katowicka Grupa Kapitałowa and the Lubelski Weggiel "Bogdanka" S.A. $[30,31,32]$. Only three of the eight entities provide relatively detailed and valuable information on CSR, innovation and environmental protection. Jastrzębska Spółka Węglowa S.A. provides information in this field, but these are very general and ideological information, while the other four entities do not present such kind of data. Only two companies, i.e. Katowicka Grupa Kapitałowa and Lubelski Węgiel „Bogdanka” S.A. publish CSR reports, with indicators of GRI (Global Reporting Initiative), only recently. This means, that both companies follow the international standard of reporting. Also, only those companies have a code of ethics, which converted the most important essential standards and values of companies. 
Table 1. CSR activities of analyzed companies [own work]

\begin{tabular}{|c|c|c|}
\hline Company name & CSR Report & The main areas of CSR activities \\
\hline Kompania Węglowa S.A. & no & $\begin{array}{l}\text { 1. Social dialogue } \\
\text { - establishing and regular contacts with the trade unions operating in Kompania } \\
\text { Węglowa S.A. and the Employers' Association of Hard Mining Coal } \\
\text { - keeping records of social dialogue in Kompania Wegglowa S.A. and correspondence in } \\
\text { this range with the trade unions and the National Labour Inspectorate } \\
\text { - keeping records and correspondence related to collective disputes, including mediation } \\
\text { - coordinating the work of thematic groups in Kompania Wegglowa S.A. in the range of } \\
\text { occupational safety, wages, employment restructuring and other cooperation with social } \\
\text { partners } \\
\text { - cooperation with the Voivodeship Commission for Social Dialogue } \\
\text { 2. Modern, organized, creative and efficient work system } \\
\text { - having a specialized and well-qualified staff } \\
\text { - integrating employees in order to the achievement of the defined objectives } \\
\text { - investing in the development of professional and personal employees and the local } \\
\text { environment } \\
\text { - motivating staff to achieve high results of work } \\
\text { - compliance with standards of safety management system and occupational health } \\
\text { standards PN-N-18001:2004 } \\
\text { - the strong association with the region, creating new jobs and contributing to the social } \\
\text { security of the inhabitants of Upper Silesia, co-cultivate its culture and traditions of } \\
\text { mining } \\
\text { 3. The Integrated Management System } \\
\text { - implementation of the Integrated Management System in accordance with the } \\
\text { requirements of ISO 9001:2008, ISO } 14001: 2004 \text { and PN-N-18001:2004 } \\
\text { - using Integrated Management System Policy, Quality Management System, } \\
\text { Environmental Management System, Occupational Safety and Health Management } \\
\text { System }\end{array}$ \\
\hline $\begin{array}{c}\text { Katowicka Grupa } \\
\text { Kapitałowa }\end{array}$ & $\begin{array}{c}\text { yes (including } \\
\text { GRI indicators } \\
\text { for 2013, } \\
2015 \text { ) }\end{array}$ & $\begin{array}{l}\text { 1. Code of Ethics } \\
\text { - contains the rules of ethics, fair competition and high standards of corporate } \\
\text { governance, a set of values } \\
\text { 2. Spokesman for Ethics } \\
\text { - counseling and care for the observance of ethical standards } \\
\text { - monitoring the observance of ethical principles } \\
\text { - the promotion of ethical behavior } \\
\text { - participation in the activities of communication and education for the benefit of the } \\
\text { company's corporate culture } \\
\text { - the prevention of social conflicts arising from the breach of the Code of Ethics } \\
\text { 3. The most important value of CSR (described in detail in the report) } \\
\text { - the promotion of cultural values } \\
\text { - improving the quality of life of the inhabitants of the district of Katowice } \\
\text { - raising awareness and knowledge of the natural sources of energy in the society } \\
\text { - supporting the education of mining in the region } \\
\text { - minimizing the negative impact on the environment } \\
\text { - engaging in charity } \\
\text { - supporting public benefit organizations } \\
\text { - the possibility of employee development through projects aimed at raising the } \\
\text { competence } \\
\text { - fair employee appraisal system } \\
\text { - encouraging employees to participate in programs that can raise the standard of living } \\
\text { of the local community } \\
\text { - achieving a policy of sustainable development - combining efforts to economic success } \\
\text { with care for the environment and society }\end{array}$ \\
\hline
\end{tabular}

\footnotetext{
${ }^{\text {a }}$ Corresponding author: kulczycka@meeri.pl
} 


\begin{tabular}{|c|c|c|}
\hline $\begin{array}{l}\text { Lubelski Węgiel } \\
\text { „Bogdanka” S.A. }\end{array}$ & $\begin{array}{l}\text { yes (including } \\
\text { GRI indicators, } \\
\text { for } 2012-13 \text {, } \\
2014 \text { ) }\end{array}$ & $\begin{array}{l}\text { 1. Code of Ethics } \\
\text { - a set of norms and values at each position and in every cell of the organization and any } \\
\text { body corporate } \\
\text { 2. Emphasis on human capital } \\
\text { - testing the organizational culture and the internal communication system } \\
\text { - the provision of adequate staff competencies through a system of training and schooling } \\
\text { - striving to develop a formalized appraisal system, reward and promotion } \\
\text { - Incentive Systems for Employees: bonuses and commendations } \\
\text { 3. Ensuring the safety and promote the development of local communities } \\
\text { - social dialogue } \\
\text { - counteracting the effects of the social consequences of mining damage } \\
\text { - activities for the local community } \\
\text { - education and development in the mining industry } \\
\text { 4. Integrated Management System } \\
\text { - compatible with PN-EN ISO } 9001: 2009 \text {, ISO } 14001: 2005 \text {, PN-N-18001:2004 } \\
\text { - Occupational Safety and Health Management System is compatible with British BS } \\
\text { OHSAS 18001:2007 }\end{array}$ \\
\hline
\end{tabular}

The activities of the analyzed entities in the field of CSR partially overlap, but as you can see they put the emphasis on different aspects of the activity in this area and given information to the general, which means that to a certain extent otherwise perceive corporate social responsibility and this confirms that Polish companies have relatively little experience and knowledge of the activities of CSR. In contrast, compliance with GRI guidelines in reporting shows that these companies follow global trends.

All the analyzed entities conduct extensive activities, mainly in the field of environmental protection and then innovation. This is due to the specific nature of their business, which permanently changes the landscape and significantly affect the environment. The scope of activities of environmental protection is broader than innovation, the reason are high costs and risks associated with the implementation of innovations. However, regulations and environmental standards, both national and international, pressure coal mining industry to reduce the negative impact on the natural environment, which indirectly is also reflected in investments and innovations.

Available information in this range is quite general and imprecise. Especially in the case of the Lubelski Węgiel „Bogdanka” S.A., which calls itself "innovation leader" and informs that has one of the most modern mine in Poland and also in the world. Unfortunately, the report does not set out specific innovative solutions, it is only given information that innovations are used and yield positive effects.

To summarize the activities of analyzed companies in the range of CSR, innovation and environmental protection must be noted that the activities in this area are certainly present. Lubelski Węgiel „Bogdanka” S.A. and Katowicka Grupa Węglowa S.A. look the best in this collation (both companies have a code of ethics and publish social reports, in contrast to Kompania Węglowej S.A.), what does not mean that the activity and information from the tested range are fully satisfactory. The indicator of the return on sales (ROS) for 2014 can confirm that - for Lubelski Węgiel „Bogdanka” S.A. amounts 13.53, for the Katowicka Grupa Węglowa S.A.13.79, while for Kompania Węglowa S.A. -1.29. The higher value of this rate means the better financial condition of the company (the company generates higher profits). Of course, the rate of ROS is influenced by many complex aspects, mainly economic, influence the rate of ROS but keep in mind that a properly executed strategy CSR can bring a lot of intangible benefits, which can then be translated into tangible benefits. In contrast, innovation (including also those related to environmental protection) can have a direct impact on the achievement of economic and financial advantage. As indicated by Bek-Gaik and Rymkiewicz (2015) [33], it is difficult to properly and accurately determine the impact of corporate social responsibility on the financial measures of achievements of the organization, and what is more, it is still not specified variable, which in a measurable way would describe the social responsibility of business - but without doubt the subject of the impact of corporate social responsibility on the financial achievements is extremely important and needs for research in this area.

Table 2 shows the activities in the range of innovation and environmental protection of analyzed companies [30, 31, 32].

\section{Summary}

The economic entities function in specific conditions economic, social, environmental, legal and organizational - which does not exempt them from the observance of international norms of behavior [11]. In recent years, CSR has become a kind of standard or required action by the environment. Due to the fact that CSR activities should be implemented at three levels: economic, social and environmental, they are strongly associated with the innovation, eco-innovation and environmental protection. Especially sectors, which heavily affect the environment and local communities. Hard coal mining is an example of such operation. Additionally, the specificity of the Polish market - the results of research conducted by the Institute for Private Enterprise and Democracy, and the Responsible Business Forum confirmed that Polish companies are increasingly using in their business CSR tools [34], however, it is still a new concept for many Polish firms. The analysis showed that Polish company of hard coal mining industry still do not treat CSR as a constant part of their management strategy, in which they could present 
innovative solutions and activities of environmental protection.

The analysis confirmed that the issues of social and environmental represent a new challenge for Polish companies of tested sector - some of them do not provide information in this area to the public information, so their activity is unknown in this field, while the other companies provide information but doing it in (more or less) a general way. Undoubtedly, entities that follow global guidelines in the field of CSR reporting, the introduction of codes of ethics or integrated management systems achieve the greatest benefits. Therefore, it is clear that the activity in these three areas: social responsibility, innovation and environmental protection brings measurable tangible and intangible effects, and could be a source of competitive advantage.

Table 2. The activities in the field of innovation and environmental protection of analyzed companies [own work]

\begin{tabular}{|c|c|c|}
\hline Company name & The main areas of innovation activities & $\begin{array}{c}\text { The main areas of environmental protection } \\
\text { activities }\end{array}$ \\
\hline $\begin{array}{c}\text { Kompania Węglowa } \\
\text { S.A. }\end{array}$ & $\begin{array}{l}\text { 1. Cooperation with research and development units, } \\
\text { local governments and economic entities, co-create } \\
\text { research-and-development projects } \\
\text { 2. Develop technology that will make coal fuel } \\
\text { environmentally friendly } \\
\text { 3. Current analysis of developments in the fuel and } \\
\text { energy sector in the country and in the world with } \\
\text { special emphasis on EU policies in these areas } \\
\text { 4. Any employee may submit a project inventive, } \\
\text { idea or technology improvement design }\end{array}$ & $\begin{array}{l}\text { 1. Compliance with the requirements in range of } \\
\text { European Union law by: } \\
\text { - design of mining operations with regard to } \\
\text { limiting the negative impact on the } \\
\text { environment, } \\
\text { - reducing the amount of waste going to dump } \\
\text { by using them for reclamation and any } \\
\text { engineering works } \\
\text { - reducing the negative impact of mining of salt } \\
\text { water to surface water } \\
\text { 2. Implementation of an Environmental } \\
\text { Management System } \\
\text { 3. Waste management in the most favorable } \\
\text { forms } \\
\text { 4. Properly planned and carried out reclamation } \\
\text { and also exploitation post-mining land, what } \\
\text { may lead to give them a new natural values, } \\
\text { often more valuable than the original }\end{array}$ \\
\hline $\begin{array}{l}\text { Katowicka Grupa } \\
\text { Kapitałowa }\end{array}$ & $\begin{array}{l}\text { Implementation of investments for the years } 2013 \text { - } \\
\text { 2020: } \\
\text { 1. The introduction of innovative methods of methane } \\
\text { drainage decks } \\
\text { 2. Heat recovery from the cooling system group } \\
\text { 3. The construction of a fossil-fuel power station for } \\
\text { low calorie fuel } \\
\text { 4. Implementation of the monitoring system of work } \\
\text { underground in the mining } \\
\text { 5. The method of pre-methane drainage and } \\
\text { gasification of coal } \\
\text { 6. Implementation of the control system powered roof } \\
\text { support, adapted for use in an unmanned longwall } \\
\text { machinery } \\
\text { 7. Implementation of the identification system for } \\
\text { monitoring employees, vehicles, machinery, } \\
\text { equipment and materials }\end{array}$ & $\begin{array}{l}\text { 1. Environmental Management System (PN-EN } \\
\text { ISO 14001:2005) } \\
\text { 2. Good environmental practices } \\
\text { - minimizing the amount of waste mining } \\
\text { - reducing the amount of waste mining together } \\
\text { with the continuation of possible maximum } \\
\text { waste management on the land and in } \\
\text { underground mines } \\
\text { - recovery of foreign waste (waste from power } \\
\text { plant) in underground mines } \\
\text { - the introduction of selection of underground } \\
\text { water } \\
\text { - identification of characteristics of methane } \\
\text { found in coal mines KHW SA } \\
\text { - intended use of methane to generate electricity } \\
\text { and heat }\end{array}$ \\
\hline $\begin{array}{l}\text { Lubelski Węgiel } \\
\text { „Bogdanka” S.A. }\end{array}$ & $\begin{array}{l}\text { 1. Cooperation with research and development units } \\
2 \text {. The leader of innovation and efficiency in the } \\
\text { domestic mining industry - the information from the } \\
\text { integrated report for } 2014 \\
\text { 3. Developing innovative technical solution entitled } \\
\text { "Frame to dump output carriage" (pol. „Rama do } \\
\text { wywrotu wozów urobkowych”) }\end{array}$ & $\begin{array}{l}\text { 1. Integrated Management System for Quality } \\
\text { \& Environment compatible with PN-EN ISO } \\
\text { 9001:2009, ISO 14001:2005, PN-N-18001:2004 } \\
\text { 2. The Book of the Integrated Management } \\
\text { System, which regulate environmental } \\
\text { management by: } \\
\text { - identification and assessment of } \\
\text { environmental aspects (PZ/S/04/01) } \\
\text { - monitoring of key characteristics of the } \\
\text { environmental aspects (PZ/S/04/02) } \\
\text { - identification of legal and other requirements } \\
\text { and assessment of conformity (PZ/S/04/03) } \\
\text { - developing environmental programs } \\
\text { (PZ/S/04/04) } \\
\text { 3. The report on environmental impact } \\
\text { 4. Waste management } \\
\text { 5. Protecting the earth's surface }\end{array}$ \\
\hline
\end{tabular}




\section{References}

1. Brakman, S., Nations and firms in the global economy: An Introduction to International Economics and Business. (Cambridge university press, 2006).

2. A. Kuzior, B. Knosala, Zesz. Nauk. PŚl., Org. Zarz. 81, 119-129 (2015)

3. H. Jenkins, Business Ethics: A European Review 18, 21-36 (2009)

4. R. E. Freeman, J. Liedtka, Business Horizons, 34(4), 92-98 (1991)

5. M. Friedman, Capitalism and freedom, (Chicago: University of Chicago Press, 1962)

6. J.J. Asongu, Journal of Business and Public Policy 1(3), 1-21 (2007)

7. G. Rexhepi, S. Kurtishi, G. Bexheti, Procedia Social and Behavioral Sciences 75, 532-541 (2013)

8. van Oppen, C.,Brugman, L. Organizational Capabilities as the Key to Sustainable Innovation. Accesable at: http://www.squarewise.com/Capabilities.pdf

9. A. Czubała, Kons. i Rozw. 1, 58-67 (2011)

10. Kromer,B. Stud. Ekonom., 180, 131-140. (2014).

11. P. Dulewicz, A. Perzyńska, K. Witkowski, Logistyka 4, 3890-4023 (2014)

12. D. Szymanek, Zrównoważony Rozwój - Debiut Naukowy 1, 97-103 (2011)

13. Mossakowska T., Wasilewski M., Przegląd Górniczy Nr 10 (1067) 66, 47-58 (2011)

14. Levy, D. L., Brown, H. S., De Jong, M. Bus. \& Soc, 49(1), 88-115 (2010)

15. A. Paszkiewicz, A. Szadziewska, Zeszyty Naukowe Uniwersytetu Szczecińskiego Nr 668 Finanse, Rynki Finansowe, Ubezpieczenia 41, 627-644 (2011)

16. R. Bocquet, C. Mothe, Revue Sciences de Gestion 80, 101-119 (2011)

17. I. Gallego-Alvarez, J. Manuel Prado-Lorenzo, I.M. Garcia-Sanchez, Management Decision 49, 1709-1727 (2011)

18. van Tonder, E., Roberts-Lombard, M. A. Journ. of Bus. \& Econ. Res., 11(12), 503 (2013)

19. Machiba T. Sustainable Manufacturing and Eco-Innovation: Framework, Practice and Measurement - Synthesis Report (Paris: OECD, 2009)

20. K. Kazojć, Ekonomia i Środowisko 3(50), 122129 (2014)

21. D. Zuzek, Rocz. Nauk. Stow. Ekon. Rol. i Agrob. 17(1), 240-244 (2015)

22. http://database.eco-innovation.eu/:

23. http://www.eco-innovation.eu/

24. http://kghm.com/pl/eko-innowator

25. https://www.nfosigw.gov.pl/

26. Kulczycka, J., Wirth, H.. Zeszyty Naukowe IGSMiE PAN 79, 147-157 (2010)

27. https://weglokoks.com.pl/organizacja wegla.pdf
28. Polski Sektor Energetyczny Raport, (Polska Agencja Informacji i Inwestycji S.A. 2012)

29. M. Białas, Materiały XXV Konferencji z cyklu Zagadnienia surowców energetycznych $i$ energii $w$ gospodarce krajowej, 17-29 (2011)

30. https://www.kwsa.pl/

31. http://www.khw.pl/\#

32. http://www.lw.com.pl/

33. B. Bek Gaik, B. Rymkiewicz, Zeszyty Naukowe Uniwersytetu Szczecińskiego Nr 854 Finanse, Rynki Finansowe, Ubezpieczenia 73, 151-166 (2015)

34. M. Ratajczak, Zeszyty Naukowe SGGW w Warszawie - Problemy Rolnictwa Światowego, 10(25), 75-82 (2010) 